ISSN 1392-3196 / e-ISSN 2335-8947

Zemdirbyste-Agriculture, vol. 107, No. 4 (2020), p. 329-336

DOI 10.13080/z-a.2020.107.042

\title{
Transcriptome changes triggered by a short-term low temperature stress in winter wheat
}

\author{
Andrius ALELIŪNAS, Kristina JAŠKŪNĖ, Gražina STATKEVIČIŪTĖ, \\ Gabija VAITKEVIČIŪTĖ, Gintaras BRAZAUSKAS, Rita ARMONIENE \\ Lithuanian Research Centre for Agriculture and Forestry, Institute of Agriculture \\ Instituto 1, Akademija, Kèdainiai distr., Lithuania \\ E-mail: andrius.aleliunas@lammc.lt
}

\begin{abstract}
Abiotic stresses alter the expression of multiple genes in plants allowing them to accommodate to hostile environmental conditions. Exposure to low temperatures in the autumn prior to winter is a crucial environmental factor determining an increase in freezing tolerance and winter hardiness in temperate plants. The objective of this study was to evaluate transcriptome changes under a short-term low temperature stress using an RNA-Seq approach in winter wheat (Triticum aestivum L.). Significant alterations were observed for nuclear transcriptome of winter wheat, whereas the expression profiles of organellar genes were much less responsive to low temperature stress. In total, there were 15,042 nuclear genes with significantly $(\mathrm{FDR}<0.05)$ altered expression profiles caused by exposure to low temperature. From this number, a total of 2,466 genes had a substantially $\left(\log _{2}\right.$ FC $>2$ or $\log _{2}$ FC $<-2$ ) affected expression profile. The highest number of upregulated genes was observed from chromosomes in homoeologous group 5, followed by group 2. Differentially expressed genes (DEGs) with the most extreme upregulation encompassed CBFIIId-12.1, WRKY transcription factor 55-like, and a group of genes related to jasmonate signalling pathway.
\end{abstract}

Key words: cold stress, differentially expressed genes, jasmonate signalling, RNA-Seq, transcription factors, Triticum aestivum.

\section{Introduction}

Bread wheat (Triticum aestivum L.) has undergone a complex history of spread, adaptation and selection since domestication $\sim 8,000-10,000$ years ago in the Fertile Crescent and has become one of the most widely cultivated crops in the world (Pont et al., 2019). Today, bread wheat is cultivated in 6 continents and occupies more than 220 million hectares, providing $20 \%$ of the protein and caloric intake of humans.

Bread wheat is allohexaploid $(2 n=6 x=42$, AABBDD) with three closely related subgenomes originated from different species by two polyploidization events (Feldman, Levy, 2012). Complex bread wheat genome of about $16 \mathrm{Gbp}$ has a very high content of long terminal repeat retrotransposons and displays high levels of similarity between the homologous gene sets on the three subgenomes. Recently, a fully annotated reference sequence of the bread wheat genome in the form of 21 chromosome-like sequence assemblies with access to 107,891 high-confidence genes was made publicly available by The International Wheat Genome Sequencing Consortium (IWGSC, 2018).

Most of the world's wheat is cultivated in temperate climate, where it is exposed to a wide range of fluctuating environmental conditions. Two main types of wheat, differing in their vernalization requirement - spring wheat (no vernalization required) and winter wheat (vernalization required), are cultivated. Winter wheat has higher yield potential; however, a lack of adequate freezing tolerance is still the main limiting factor in some regions (Fowler, Limin, 1997). Freezing tolerance of winter cereals develops through the process of cold acclimation, which is triggered by upregulation or downregulation of hundreds to thousands of cold regulated $(C O R)$ genes after exposure of plants to low but non-freezing temperature for certain periods of time (Laudencia-Chingcuanco, Fowler, 2012; Li et al., 2018).

Transcriptional cascade of Inducer of $\mathrm{CBF}$ Expression (ICE)-C-Repeat-Binding Factors (CBF)$\mathrm{COR}$ is the only well-characterized cold acclimation signalling pathway, which is suggested to be functionally conserved in different plant species. In this pathway, CBFs are rapidly induced by inducer of ICE1 during cold stress and bind to the promoter regions of $C O R$ genes, known as the $\mathrm{CBF}$ regulon, to activate their transcription (Chinnusamy et al., 2007). Although the CBF-dependent pathway plays a crucial role in cold acclimation, only 10

Please use the following format when citing the article:

Aleliūnas A., Jaškūnė K., Statkevičiūtė G., Vaitkevičiūtė G., Brazauskas G., Armonienė R. 2020. Transcriptome changes triggered by a short-term low temperature stress in winter wheat. Zemdirbyste-Agriculture, 107 (4): 329-336. DOI 10.13080/z-a.2020.107.042 
$25 \%$ of $C O R$ genes are controlled by CBFs, as revealed by transcriptome analysis (Park et al., 2015).

In wheat, two freezing tolerance loci, known as Frost resistance-1 $(F r-1)$ and $F r$-2, were identified, both of which are located on the long arm of group 5 homoeologous chromosomes (Båga et al., 2007). Fr-1 is mostly like the Vernalization-1 (Vrn-1) gene, which exhibits pleiotropic effects (Laudencia-Chingcuanco et al., 2011). Increased transcription levels of the Vrn1 gene during exposure to low temperatures trigger the transition from the vegetative to reproductive growth stage and reduce freezing tolerance (Dhillon et al., 2010). In addition, CBF genes have also been shown to repress/ delay plant growth (Park et al., 2015). Transcriptomic analysis of wheat during cold acclimation in field conditions showed gradual up-regulation of abscisic acid-dependent and CBF pathways in the crowns. This was accompanied by the downregulation of key genes involved in meristem development as the autumn progressed (Li et al., 2018).

In this study, the transcriptome changes of the winter wheat cultivar 'Gaja DS' triggered by a shortterm low $\left(2^{\circ} \mathrm{C}\right)$ temperature treatment in comparison to the control plants (no exposure to low temperature) was described. Organellar and nuclear transcriptome response to a short-term low temperature stress in winter wheat is further evaluated.

\section{Materials and methods}

Plant material and growth conditions. The experiment was carried out at the Institute of Agriculture, Lithuanian Research Centre for Agriculture and Forestry in 2019. Lithuanian winter wheat (Triticum aestivum L.) cultivar 'Gaja DS', characterized as winter-hardy and well-adapted to temperate climate conditions (Ruzgas, Koppel, 2017), was used in this study. Pre-germinated seeds were planted in peat moss potting substrate. Seedlings were grown under semi-controlled conditions in the greenhouse for a three-week period maintaining 18/6 h photoperiod, $20 / 16^{\circ} \mathrm{C}$ day/night ambient temperature. Prior to the low temperature treatment, the plants were transferred to a PlantMaster (CLF Plant Climatics GmbH, Germany) phytotron set at $20^{\circ} \mathrm{C}$ temperature, $200 \mu \mathrm{mol}$ $\mathrm{m}^{-2} \mathrm{~s}^{-1}$ photosynthetically active radiation (PAR), 18/6 h photoperiod and $80 \%$ relative air humidity for seven days until the plant reached five-leaf (Zadoks 15) stage (Zadoks et al., 1974). The low temperature treatment procedure was performed in the phytotron, at the same growth chamber by gradually lowering temperature at the rate of $-2^{\circ} \mathrm{C}$ per hour before ambient temperature of $2^{\circ} \mathrm{C}$ was reached. The lowering of the temperature down from $20^{\circ} \mathrm{C}$ to $2^{\circ} \mathrm{C}$ took $9 \mathrm{~h}$, and the cold stress at $2^{\circ} \mathrm{C}$ lasted for $15 \mathrm{~h}$ before the second sampling.

Plant sampling and RNA extraction. Prior to exposure to the low temperature, $20 \mathrm{mg}$ segments of pathogen-free tissue were excised from three fully developed separate leaves. The segments were pooled to form a joint leaf sample and were flash-frozen in liquid nitrogen. At the end of the low temperature treatment procedure, leaf sampling was repeated to collect plant material of cold treated plant. Sampling procedures for control and cold treated plants were performed in the middle of the photoperiod light cycle. The extraction of total RNA was performed as per manufacturer's guidelines using GeneJET Plant RNA Purification Kit (Thermo Fisher Scientific, Lithuania). Residual genomic DNA contamination was eliminated by treating RNA samples with Dnase I, RNase-free (Thermo Fisher
Scientific). Afterwards, the samples were cleaned using RNeasy Plant Mini Kit (Qiagen, Germany) spin columns using a custom lab protocol. Purified total RNA was precipitated and resuspended in RNase-free water at a final concentration of $100 \mathrm{ng} \mathrm{uL}{ }^{-1}$. RiboLock RNase inhibitor (Thermo Fisher Scientific) at a concentration of $1 \mathrm{U} \mu \mathrm{l}^{-1}$ was added to protect RNA samples from degradation. RNA yield and purity were determined spectrophotometrically using Nanodrop 1100 (Thermo Scientific, USA).

RNA-Seq library preparation, sequencing and data analysis. rRNA depletion in total RNA samples was performed using Ribo-Zero ${ }^{\mathrm{TM}}$ rRNA Removal Kit (Plant) (Illumina, USA). Afterwards, four stranded cDNA libraries (two for control and two for low temperature treated sample) were prepared using Collibri Stranded RNA Library Prep Kit for Illumina System (Thermo Fisher Scientific). NovaSeq 6000 System (Illumina) platform equipped with S4 flow cell was used for $150 \mathrm{bp}$ paired-end (PE) sequencing at Thermo Fisher Scientific facilities. cDNA libraries were sequenced on two flow cells in pairs, and each pooled RNA sample was sequenced in four technical replicates. For the quality control (QC) of raw sequencing reads, FASTQ files were evaluated by FastQC (Andrews, 2010) to check for sequencing anomalies quality trimming was performed using TrimGalore (https://github.com/FelixKrueger/ TrimGalore) to remove low quality base calls (Phred score $<20$ ) from the 3' end of the reads. If present, Illumina paired-end sequencing adapters were trimmed off.

Forward reads of paired-end read pairs were retained and trimmed to $75 \mathrm{bp}$ from 3' end for differential expression analysis. After quality control, low quality base and adapter trimming, reads were mapped to a reference genome and transcriptome using two approaches. Reads were mapped to T. aestivum cultivar 'Chinese Spring' organellar reference chloroplast MH051715.1 (135,905 bp) (IWGSC, 2018) and mitochondrion NC 036024.1 (452,526 bp) genomes using STAR (version 2.7.0 c) aligner (Dobin et al., 2013). Genome indices were built using default STAR parameters and --genomeSAindexNbases of 7 and 8 for chloroplast and mitochondrion genomes, respectively. Single-end (SE) reads, which could not be aligned to organellar genomes, were retained and pseudo-aligned to a reference transcriptome and quantified using kallisto (Bray et al., 2016). To evaluate the expression profiles of nuclear genes, advantage of the recently published spring wheat 'Chinese Spring' RefSeq Annotation, version 1.1 (IWGSC, 2018) was taken. High confidence (HC) gene classes were included in the differential expression analysis, which encompassed 107,888 unique genes (133,744 transcripts including isoforms) (Alaux et al., 2018).

Differentially expressed genes (DEGs) analysis was performed using the count-based statistical method implemented in DESeq2, version 1.22.2 (Love et al., 2014). Approximate posterior estimation for general linear model (GLM) coefficients was performed using package apeglm (Zhu et al., 2019), while for the correction of multiple testing False discovery rate (FDR) method (Benjamini, Hochberg, 1995) was used. Gene ontology (GO) annotations for protein coding transcripts were inferred using InterProScan, version 5.36-75.0 (https://github.com/ebi-pf-team/interproscan) by searching signature databases Pfam, PROSITE, PRINTS, ProDom, SMART, TIGRFAMs, PIRSF, SUPERFAMILY, Gene3D and PANTHER. GO terms enrichment was carried out using package top $G O$, version 2.34.0 (Alexa, Rahnenfuhrer, 2018) for $R$, whereas $p$-values were 
calculated using Fisher's exact test. The gene universe for $\mathrm{GO}$ enrichment analysis was comprised of 47,493 gene transcripts with $\mathrm{GO}$ annotations.

Statistical analysis was performed using program $R$, version 3.6.0 (R Core Team, 2019). Mean \pm SE (standard error of mean) were used to describe the variability of measurements where applicable.

\section{Results and discussion}

Sequencing data analysis. Four stranded RNA-Seq libraries derived from two (control and low temperature treated) pooled RNA samples were sequenced in two technical replicates and yielded more than 372 million high-quality paired-end reads in total. The number of raw reads ranged from 37 million to 53 million depending on the library and flow cell. After quality trimming, a small fraction of reads was discarded from the analysis, and there were still between 34 and 52 million cleaned high-quality reads per library remaining. For differential gene expression analysis, forward reads of PE read pairs and trimmed the reads from 3' end to $75 \mathrm{bp}$ in length to reduce computational burden was used. As the same libraries were sequenced twice on two individual flow cells, inconsistency of sequencing read number per flow cell was observed. A second flow cell yielded substantially less sequencing reads with an average of 41,805,003.00 $\pm 3,373,679.72$ per library, while for the first flow cell the average read number was higher with an average of 50,645,487.75 $\pm 3,838,404.47$ reads. Due to significant inconsistency in read numbers between the flow cells, flow cells as a batch effect covariate into the analysis was assigned. Principal component analysis (PCA) clearly separated transcriptomes of low temperature treated and control plants, both in original, and corrected for the batch effect data sets (Fig. 1).

Prior to the correction for the batch effect, PC1 explained 0.97 of observed variance due to low temperature treatment, whereas PC2 explained only 0.02 of residual variation. The inclusion of a batch covariate into experimental design did not yield a noticeable effect, as almost equivalent fractions of variation of 0.98 and 0.01 were explained by PC1 and PC2, respectively. Overall, it was evident that the batch effect was nonsignificant, despite substantial differences in sequencing read quantity between the flow cells.

Organellar transcriptome under short-term low temperature stress. A large fraction, an approximately half of the sequencing reads, were originated from the chloroplast genome. In the control plant, $56.13 \pm 0.63 \%$ of reads were of chloroplast-origin. However, in the low temperature treated plant the portion of chloroplast reads dropped considerably and comprised $50.39 \pm$ $0.92 \%$ of total reads on average. It is worth noting, that the sampling for both control and cold treated plant was performed in the middle of the photoperiod light cycle. The observed decrease in chloroplast read fraction in the low temperature treated plant might be attributed either to increased expression of nuclear genes or to repression of chloroplast genes.

A large amount of chloroplast transcripts is not surprising, as organelles are found in large quantities in plant cells (Cole, 2016). However, the predominance of chloroplast transcripts in winter wheat transcriptome was in stark contrast to abundance ofmitochondrion transcripts. Sequencing reads, which were mapped to mitochondrion genome comprised only $1.58 \pm 0.02 \%$ and $1.40 \pm 0.01 \%$ of all reads on average for control and low temperature treated plant, respectively. Expression profiles for 84 protein-coding genes encoded by chloroplast genome were examined in this study. It was evident that the expression of protein-coding genes was not substantially altered by low temperature treatment, and $\log _{2} \mathrm{FC}$ (fold change) for the identified differentially expressed genes (DEGs) ranged from -0.79 to 1.35 . As such, gene for photosystem II protein $\mathrm{N}$ (psbN) was downregulated the most, while a slight increase in transcript abundance was observed for the ribosomal protein L2 ( $r p l 2)$ gene. Leonardos et al. (2003) observed an obvious decline in photosynthesis rate in low temperature stressed winter wheat. However, this phenomenon cannot be explained directly by transcriptional activity of protein-coding genes, as no substantial perturbations in the chloroplast transcriptome was observed. Nonetheless, because of reductive genome evolution, organelles rely heavily on nuclear expression (Martin, Herrmann, 1998), thus it might be impossible to evaluate chloroplast activity by examining chloroplastic gene expression alone.

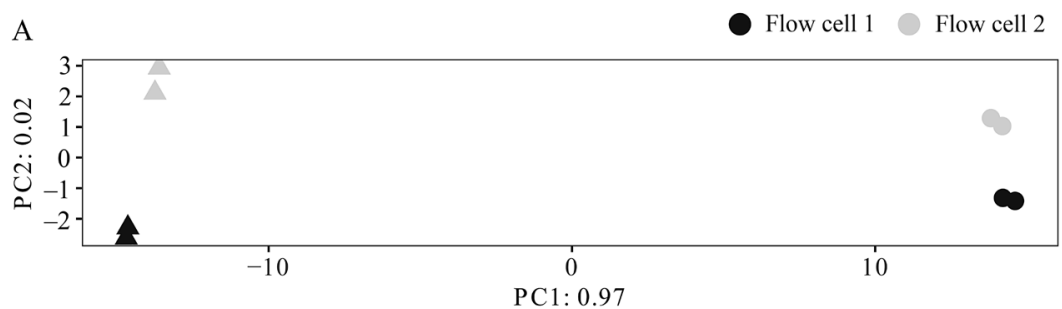

B

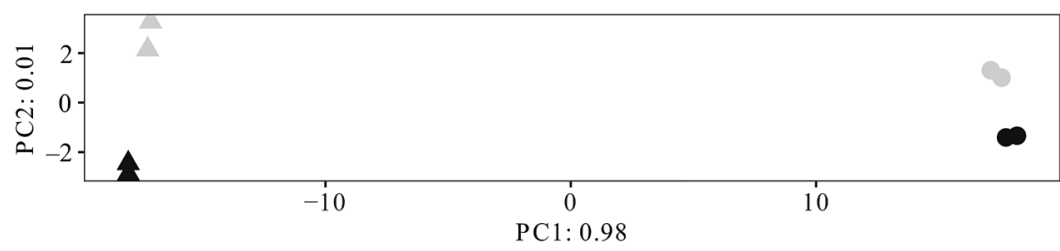

Note. Triangles represent samples exposed to short-term low temperature, while the circles denote control samples; most of the observed variance in gene expression can be explained by exposure to low temperature (PC1), while only a small fraction of observed variance occurred because of the batch effect.

Figure 1. Principal component analysis (PCA) plot visualizing the overall effect of experimental covariates and batch effects for RNA-Seq data before (A) and after (B) the correction for the batch effect 
Mitochondrion transcript abundance for 36 protein-coding genes in control and low temperature treated plants was additionally examined. Similarly, as for chloroplast transcriptome, low temperature stress had no clearly pronounced effect on transcriptional activity of mitochondrion genes. Moreover, mitochondrion genes demonstrated more stable expression under cold stress when compared to chloroplast genes, as $\log _{2} \mathrm{FC}$ values for mitochondrion DEGs were lower and ranged from -0.77 to 0.40 at $\mathrm{FDR}<0.05$. A short-term low temperature treatment had the largest effect on downregulation of ribosomal protein S3 (rp13) gene in mitochondrion transcriptome, while the strongest upregulation was observed for ribosomal protein S7 (rps7) gene.

Nuclear transcriptome alterations under shortterm low temperature stress. Significant alterations were observed in nuclear transcriptome of winter wheat in comparison with organellar (Fig. 2). After correction for multiple testing, 15,042 nuclear genes with significantly (FDR < 0.05) low temperature treatmentaffected expression profiles were identified. $\log _{2} \mathrm{FC}$ for nuclear DEGs ranged broadly from -8.89 to 12.80 , and significant DEGs represented $23.87 \%$ of all $(63,016)$ expressed genes. In total, 8,798 DEGs were significantly upregulated $\left(\log _{2} \mathrm{FC}>0, \mathrm{FDR}<0.05\right)$ by a short-term low temperature treatment, while the transcription for other 6,244 DEGs was repressed $\left(\log _{2} \mathrm{FC}<0\right.$, FDR $<$ $0.05)$. The expression of 314 genes was observed only in low temperature treated plant and was not evident in the control plant.

Genes with expression profiles, strongly affected by low temperature treatment $\left(\log _{2} \mathrm{FC}>2\right.$ or $\log _{2}$ FC $<-2$, FDR $\left.<0.05\right)$, were analysed separately and settled with 2,466 such genes. It was evident that low temperature treatment had a substantial effect on transcriptional activation, compared to repression for these strongly affected DEGs. A vast majority, 1,988 $(80.62 \%)$ of the DEGs were upregulated, whereas 478 $(19.38 \%)$ of the DEGs were repressed. A significant correlation between the chromosomal gene content and DEGs was also observed. There was a clear near-linear relationship between chromosomal high confidence gene content and the number of strongly upregulated DEGs $\left(r^{2}=0.88, p<0.001\right)$. For low confidence (LC) genes, the relationship was much less pronounced and nonsignificant $\left(r^{2}=0.335, p=0.126\right)$. As low confidence genes represent partially supported gene models, gene fragments and orphans (IWGSC, 2018), our finding supports the fact that a large fraction of low confidence genes might represent inactive genetic elements.
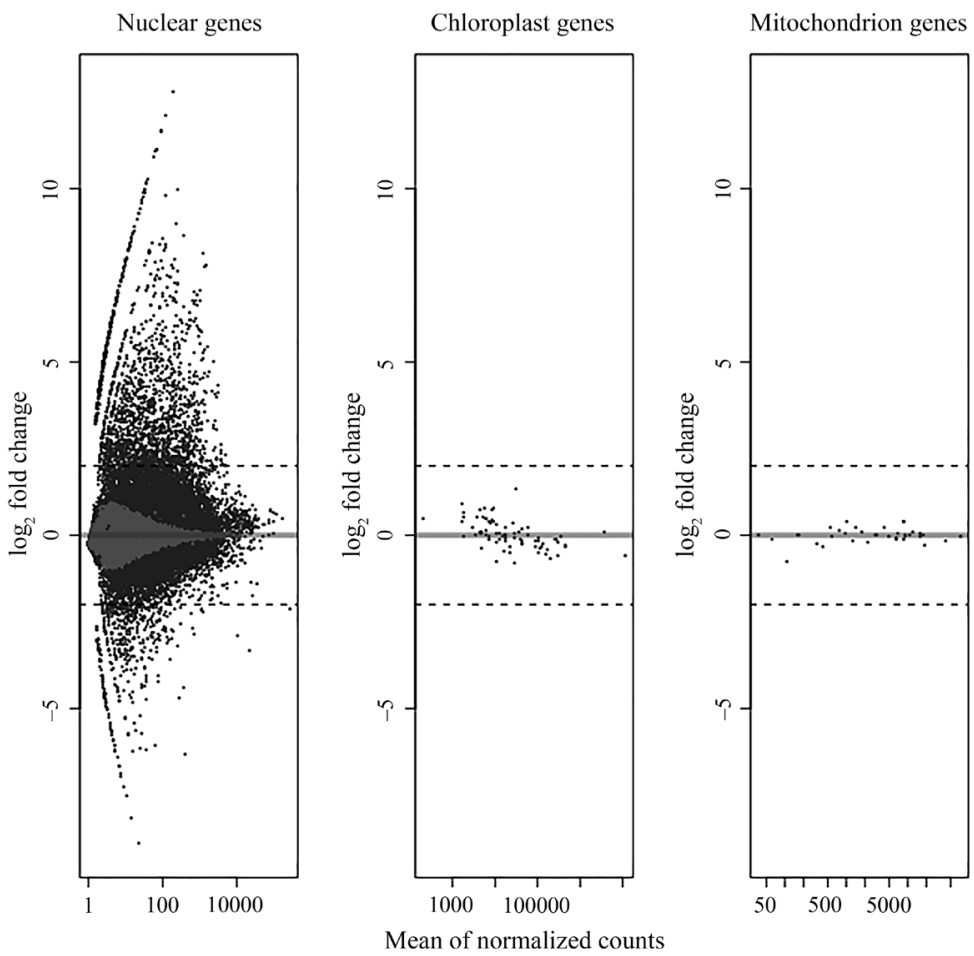

Note. Individual gene responses are represented as $\log _{2} \mathrm{FC}$ (fold change); a negative change represents downregulated genes while a positive change represents the upregulated genes; genes, which fall under the significance level of FDR $<0.05$ are plotted in black; dashed lines show the thresholds of $\log _{2} \mathrm{FC}$ at 2 and -2 .

Figure 2. MA plot of differentially expressed genes (DEGs) in winter wheat grown under normal conditions and subjected to a short-term low temperature treatment

Strongly upregulated genes were not equally distributed across the wheat chromosomes. In terms of individual chromosomes, low temperature treatment upregulated the largest number (144) of transcripts from chromosome 5D, while the least number (66) of upregulated genes originated from chromosome 4B (Fig. 3). The number of upregulated genes was also the highest in chromosomes 5 in all wheat subgenomes with an average number of $124.67 \pm 17.47$, followed by chromosome 2 with an average number of $117 \pm 6$ genes per A, B and D subgenomes.

As was observed in the current study, high gene expression in the homoeologous group 5 chromosomes of wheat subgenomes could be explained by the fact that chromosome group 5 is associated with freezing tolerance in Triticeae (Tondelli et al., 2011). The contribution of transcriptional upregulation due to low temperature treatment was not equal in terms of wheat subgenomes 


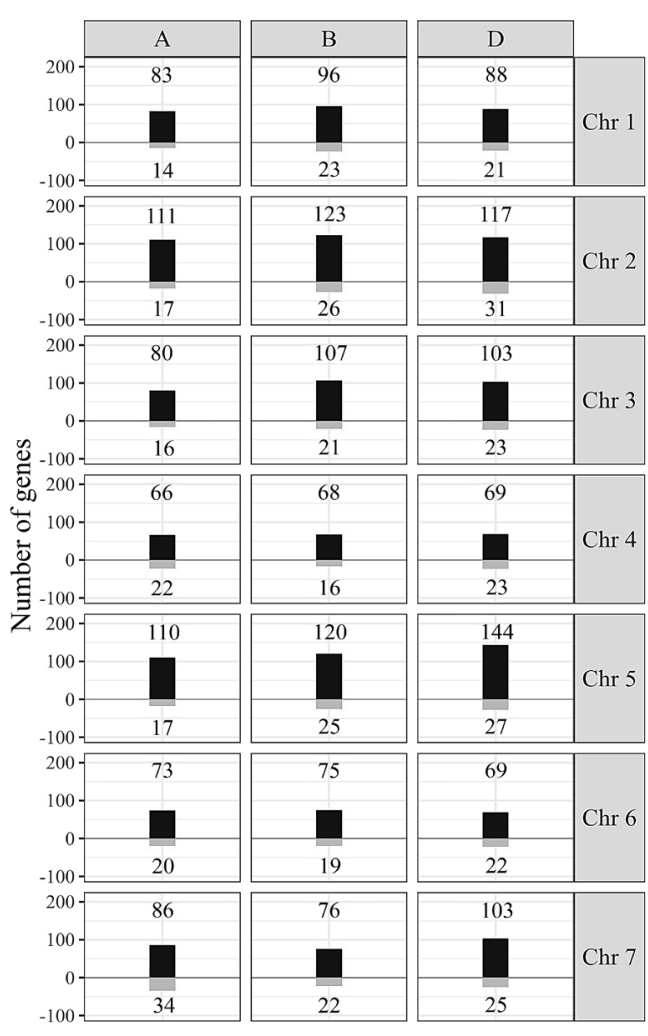

Note. Only genes with strongly affected expression $\left(\log _{2} \mathrm{FC}\right.$ (fold change) $<-2$ and $\log _{2} \mathrm{FC}>2$ ) are shown; black bars denote upregulated genes, while grey bars represent repressed ones; the number of upregulated and downregulated genes is given for each chromosome.

Figure 3. The effect of a short-term low temperature treatment on gene expression of distinct chromosomes and subgenomes in winter wheat

representation, as 609 of the transcripts originated from subgenomes A, 665 from B, whereas the largest number (693) of strongly upregulated gene transcripts were mapped to wheat chromosomes of subgenome D.

Genes strongly upregulated by a short-term low temperature stress. The DEGs with significant upregulation $\left(\log _{2}\right.$ FC in range of 9.89-12.80) caused by exposure to low temperature contained CBFIIId-12.1, TIFY 11e-like, WRKY transcription factor 55-like, cytochrome P450 94Cl-like, thaumatinlike, phenylalanine ammonia-lyase-like and ethyleneresponsive transcription factor ERF109-like genes. As winter wheat genes might exist as a trio of A, B and $\mathrm{D}$ homoeoloci, synchronized upregulation of TIFY 1le-like (three discrete loci in 7D, one in 7A and 7B chromosomes), ERF10 (two discrete loci in 1D and one in 1A) and cytochrome P450 94Cl-like (5A and 5B) genes were observed under low temperature treatment. However, the strongest upregulation by low temperature was noted for CBFIIId-12.1 ( $\log _{2}$ FC of 12.11), a member of C-Repeat-Binding Factor $(\mathrm{CBF})$ transcription factor family crucial for freezing tolerance in plants (Badawi et al., 2007).

A group of genes related to jasmonate (JA) mediated signalling pathway was also strongly induced by low temperature. The group encompassed TIFY11elike (mean $\log _{2}$ FC $10.90 \pm 0.86$ ), P450 94C1-like (mean $\log _{2} \mathrm{FC} 11.00 \pm 0.13$ ) and ethylene-responsive transcription factor ERF10 $\left(\log _{2}\right.$ FC of $\left.10.03 \pm 0.16\right)$ genes. Here, TIFY11e represents a key regulator in the jasmonate signalling pathway (Chini et al., 2007). Data concerning the involvement of TIFY genes in cold stress response is scarce. As there are at least 49 TIFY genes in all wheat subgenomes (Ebel et al., 2018), it was observed that TIFY11e-like expression was most affected by a short-term low temperature treatment in winter wheat. In addition, low temperature stress caused a substantial upregulation of P450 94C1-like gene, which is involved in a major catabolic route for JA-Ile hormone (Heitz et al., 2012). Moreover, ERF109-like gene, which mediates crosstalk of jasmonate and auxins (Cai et al., 2014) was strongly upregulated. It is speculated that ERF109 gene might function in environmental signal transduction pathway (Nakano et al., 2006).

Genes strongly downregulated by a shortterm low temperature stress. Teosinte Branched 1-like (TB1-like), cation/H(+) antiporter 20-like (CHX20like), G1-like3, aluminum-activated malate transporter 10 (ALMT10), glycine-rich cell wall structural protein 2-like and TCP15-like along with polyamine oxidase-like gene were most repressed by a low temperature stress. Homologous TB1-like genes were strongly downregulated by low temperature from wheat chromosomes $5 \mathrm{~A}$ and $5 \mathrm{D}\left(\log _{2} \mathrm{FC}\right.$ of $\left.-8.52 \pm 0.52\right)$. A study by Dixon et al. (2018) showed that increased dosage of TB1 reduces tiller numbers in wheat. Moreover, TB1 is a major effect quantitative trait locus (QTL) for morphological evolution from teosinte to maize and plays a role in plant architecture control (Doebley et al., 1997), functioning down-stream of auxin and MAX-related hormonal signals (Hubbard et al., 2002; Finlayson, 2007). As a sharp decline was observed in TB1-like transcripts in low temperature treated wheat, this event might signal transition from apical growth pattern to tillering stage. This finding could at least provide partial hint on the tillering process initiation by low temperatures in wheat. Moreover, along with significant downregulation of TB1-like gene, a transcription factor TCP15-like gene was also severely repressed. A TCP15-like (TEOSINTE $B R A N C H E D 1 / C Y C L O I D E A / \underline{P C F}$ 15) transcription factor gene is involved in plant development processes and auxin homeostasis regulation, and some the TCP (Teosinte branched1/Cincinnata/proliferating cell factor) family genes are also associated with plant architecture control (Koyama et al., 2007). A strong repression of several other genes: CHX20-like, ALMT10 and polyamine oxidase-like (POA-like), might reflect adjustment of photosynthetic rate under cold stress. There are several parallels between CHX20-like, ALMT10 and POA-like, as the genes play a role in stomatal conductance control (Padmanaban et al., 2007; Gemes et al., 2016; Medeiros et al., 2018).

C-Repeat-Binding Factor (CBF) gene expression profiles. $\mathrm{CBF}$ genes have a central role in freezing tolerance and are activated by low temperature in plants (Chinnusamy et al., 2007). In our study, expression of $35 \mathrm{CBF}$ genes encoded by chromosome 5 of $\mathrm{B}$ and $\mathrm{D}$ subgenomes under a short-term low temperature treatment was evaluated (Fig. 3). In control plant, the expression for the majority of examined CBF genes was very low, except for $C B F I V b-D 20$ and $C B F I V d-D 9$. The latter genes demonstrated relatively high transcription levels in leaves even before plant exposure to low temperature (Fig. 4). Badawi et al. (2007) revealed that some CBFs from CBFIIId and CBFIV groups, including $C B F I V b-D 20$ and $C B F I V d-D 9$, show diurnal fluctuation. The highest expression of these genes was detected at 8-14 h after dawn under long day conditions. As observed 


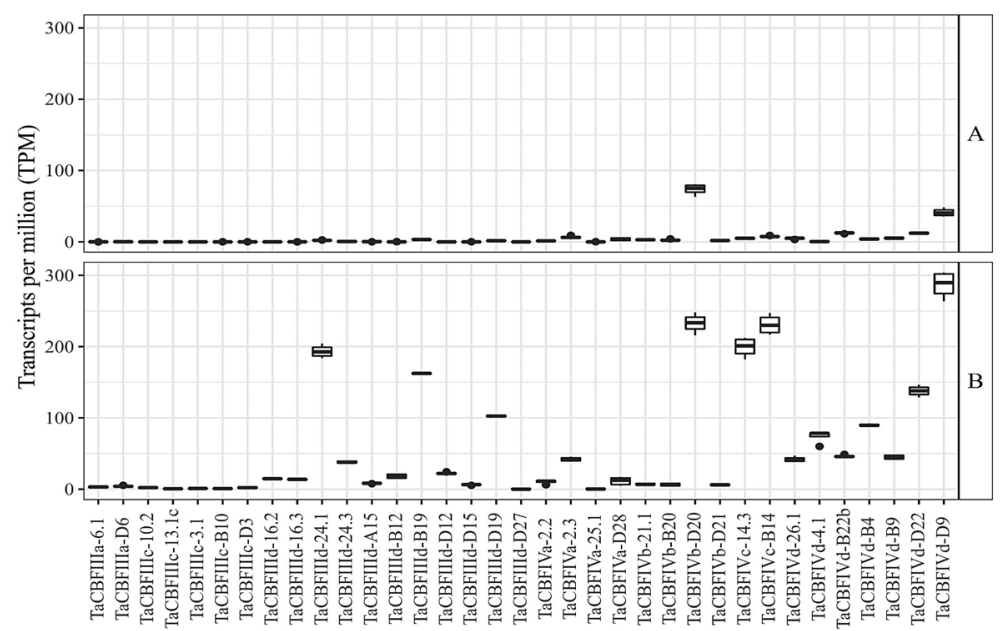

Figure 4. Expression profiles of C-Repeat-Binding Factor (CBF) genes encoded by chromosome 5 of B and D subgenomes in control plant (A) and in plant exposed to low temperature (B)

in our study, relatively high expression of $C B F I V b-D 20$ and $C B F I V d-D 9$ in the control plant could be explained by these diurnal fluctuations, as the sampling was performed $8 \mathrm{~h}$ after the start of the photoperiod.

Most of the CBF members of groups IIId and $\mathrm{IVa} / \mathrm{b} / \mathrm{c} / \mathrm{d}$ showed increased transcript level after exposure to low temperature, while expression of $\mathrm{CBF}$ genes from groups IIIa and IIIc remained unchanged.
The highest increase in transcript abundance under low temperature stress was observed for $C B F I V b-D 20$, CBFIVC-B14, CBFIIId-24.1, CBFIVd-D9, CBFIIId-B19 and CBFIVd-D22 genes. And conversely, CBFs belonging to groups IIIa and IIIc were not induced by a short-term low temperature treatment at the time of leaf sampling (Fig. 5).

A

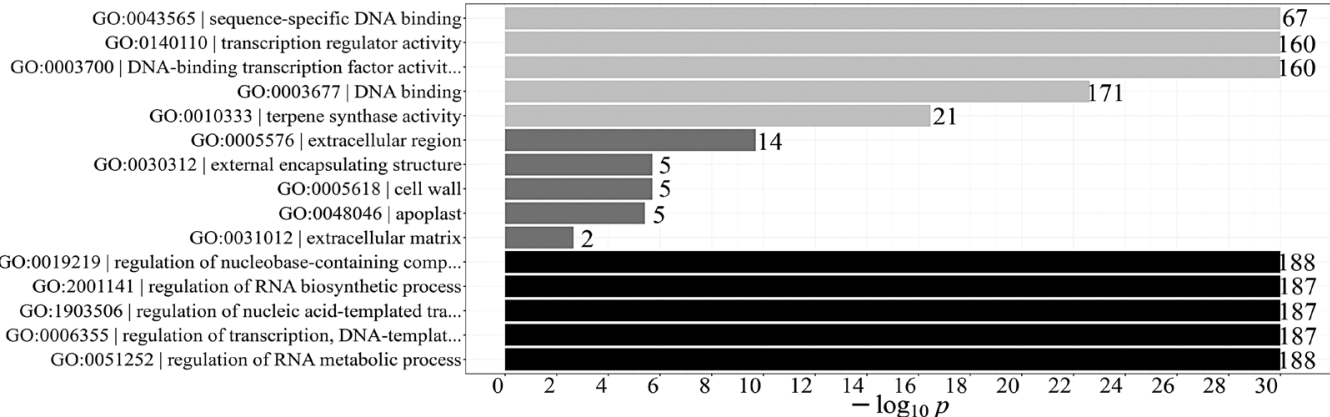

B GO:0016705 | oxidoreductase activity, acting on paire...

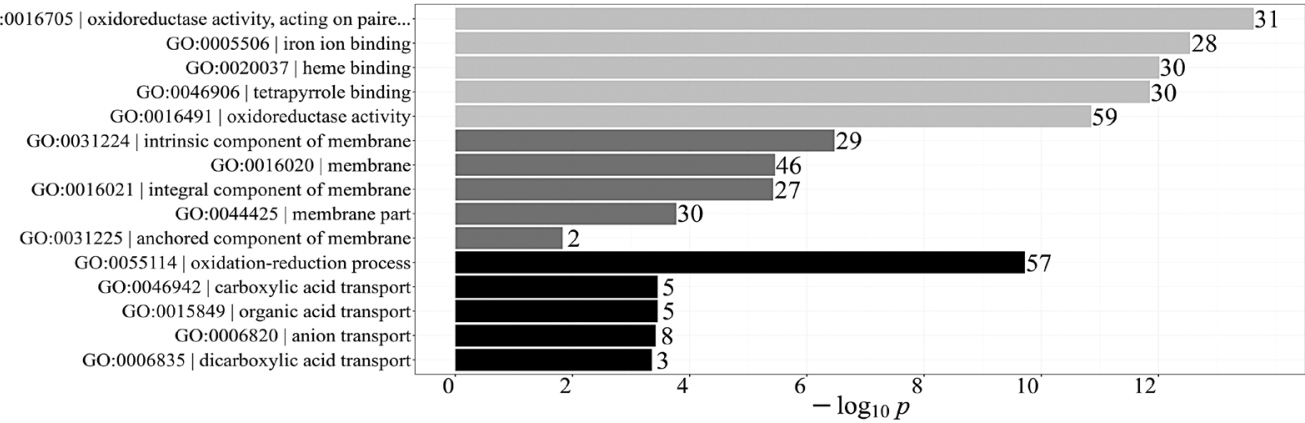

Note. The most significantly enriched GO terms are shown on the left and the number of genes associated to corresponding GO terms is shown next to the bars; enrichment scores (as $-\log _{10} p$ values) are represented on the $\mathrm{x}$ axis; light grey bars represent Molecular function, while dark grey bars represent Biological process, and black bars represent Cellular component super categories.

Figure 5. Gene ontology (GO) term enrichment analysis for gene sets strongly upregulated (A) and downregulated (B) by a short-term low temperature stress in winter wheat

Badawi et al. (2007) reported that CBFs in groups IIIa and IIIc might be expressed transiently within $2 \mathrm{~h}$ of low temperature stress and the expression quickly decays afterwards. Therefore, leaf sampling after $15 \mathrm{~h}$ of cold stress as was done in our study possibly did not coincide with peak expression of CBFs from groups IIIa and IIIc.

Gene ontology (GO) of DEGs. GO enrichment analysis was performed for the DEGs with expression profiles strongly affected $\left(\log _{2} \mathrm{FC}>2\right.$ or $\log _{2} \mathrm{FC}<$ -2 , FDR $<0.05$ ) by low temperature stress. There are indications that functionally linked genes correlate in expression levels (Hong et al., 2013). For this reason, upand downregulated genes were analysed separately. For strongly induced DEGs, 132 GO terms were significantly $(p<0.05)$ enriched in the super categories of molecular function (59), biological process (64) and cellular component (9). The most significantly enriched GO 
terms for each super category are shown in Figure 5. The most significant GO terms in molecular functions super category for nuclear DEGs were related to sequencespecific DNA binding, transcription regulator activity, DNA-binding transcription factor activity, DNA-binding and terpene synthase activity, all of them being highly significant $\left(-\log _{10} p \geq 30\right)$.

The affected cellular component was the extracellular component in general, along with the apoplast, as affected components included the extracellular region (14 genes), external encapsulating structure (5), cell wall (5), apoplast (5) and extracellular matrix (2). The most affected biological processes encompassed the regulation of RNA metabolic and biosynthetic processes. For the strongly repressed genes, GO terms were significantly $(p<0.05)$ enriched in molecular function (45), cellular component (5) and biological process (64) super categories. The top molecular functions of repressed genes corresponded to oxidoreductase activity, acting on paired donors (31 genes), followed by iron ion binding (28), heme binding (30), tetrapyrrole binding (30) and oxidoreductase activity (59). All five significantly enriched GO terms for cellular component were associated with membrane or membrane components. The dominant biological processes repressed by low temperature stress were associated with oxidationreduction and transport functions.

\section{Conclusions}

1. A short-term low temperature treatment had rather profound effect on nuclear transcriptome in winter wheat, significantly altering the expression of 15,042 out of 107,888 examined genes.

2. For the nuclear genes with expression profiles strongly affected by low temperature $\left(\log _{2} \mathrm{FC}>2\right.$ or $\log$ $\mathrm{FC}<-2)$ transcriptional induction clearly dominated over transcriptional repression.

3. Organellar transcriptome was only slightly affected by a short-term low temperature stress in winter wheat. The effect on protein-coding gene expression profiles was more pronounced in chloroplast than mitochondrion.

4. Given highly increased expression for a group of genes related to jasmonate signalling pathway, it is likely that jasmonate plays a crucial role in early response to low temperature stress in winter wheat.

\section{Acknowledgements}

The authors would like to thank Thermo Fisher Scientific Lithuania for the opportunity to use sequencing service and Aliona Markina (Thermo Fisher Scientific, Lithuania) for preparation of RNA-Seq libraries. This work was carried out within the framework of Lithuanian Research Centre for Agriculture and Forestry's long-term research program "Genetics and direct genotype development of agricultural and forestry plants". This work was partially funded by the Research Council of Lithuania, grant No. DOTSUT-218 (01.2.2-LMT-K-718-01-0065).

Received 07012020

Accepted 17072020

\section{References}

1. Alaux M., Rogers J., Letellier T., Flores R., Alfama F., Pommier C., Mohellibi N., Durand S., Kimmel E., Michotey C., Guerche C., Loaec M., Lainé M., Steinbach D., Choulet F., Rimbert H., Leroy P., Guilhot N., Salse J., Feuillet C., Paux E., Eversole K., Adam-Blondon A. F., Quesneville H. 2018. Linking the International Wheat
Genome Sequencing Consortium bread wheat reference genome sequence to wheat genetic and phenomic data. Genome Biology, 19 (1): 111.

https://doi.org/10.1186/s13059-018-1491-4

2. Alexa A., Rahnenfuhrer J. 2018. topGO: enrichment analysis for gene ontology. $R$ package version 2.34.0.

3. Andrews S. 2010. FastQC: a quality control tool for high throughput sequence data. http://www.bioinformatics. babraham.ac.uk/projects/fastqc

4. Badawi M., Danyluk J., Boucho B., Houde M., Sarhan F. 2007. The CBF gene family in hexaploid wheat and its relationship to the phylogenetic complexity of cereal CBFs. Molecular Genetics and Genomics, 277 (5): 533-554. https://doi.org/10.1007/s00438-006-0206-9

5. Båga M., Chodaparambil S. V., Limin A. E., Pecar M. Fowler D. B., Chibbar R. N. 2007. Identification of quantitative trait loci and associated candidate genes for low-temperature tolerance in cold-hardy winter wheat. Functional and Integrative Genomics, 7: 53-68. https://doi.org/10.1007/s10142-006-0030-7

6. Benjamini Y., Hochberg Y. 1995. Controlling the false discovery rate: a practical and powerful approach to multiple testing. Journal of the Royal Statistical Society. Series B (Methodological), 57 (1): 289-300. https://doi.org/10.1111/j.2517-6161.1995.tb02031.x

7. Bray L. N., Pimentel H., Melsted R., Pachter L. 2016. Near-optimal probabilistic RNA-seq quantification. Nature Biotechnology, 34: 525-527. https://doi.org/10.1038/nbt.3519

8. Cai X. T., Xu P., Zhao P., Liu R., Yu L., Xiang C. 2014. Arabidopsis ERF109 mediates cross-talk between jasmonic acid and auxin biosynthesis during lateral root formation. Nature Communications, 5: 5833. https://doi.org/10.1038/ncomms6833

9. Chini A., Fonseca S., Fernandez G., Adie B., Chico J. M., Lorenzo O., García-Casado G., López-Vidriero I., Lozano F. M., Ponce M. R., Micol J. L., Solano R. 2007. The JAZ family of repressors is the missing link in jasmonate signalling. Nature, 448: 666-671. https://doi.org/10.1038/nature06006

10. Chinnusamy V., Zhu J., Zhu J. 2007. Cold stress regulation of gene expression in plants. Trends in Plant Science, $12(10)$ 444-451. https://doi.org/10.1016/j.tplants.2007.07.002

11. Cole L. W. 2016. The evolution of per-cell organelle number. Frontiers in Cell and Developmental Biology, 4: 85. https://doi.org/10.3389/fcell.2016.00085

12. Dhillon T., Pearce S. P., Stockinger E. J., Distelfeld A., Li C., Knox A. K. 2010. Regulation of freezing tolerance and flowering in temperate cereals: the $V R N-1$ connection. Plant Physiology, 153: 1846-1858. https://doi.org/10.1104/pp.110.159079

13. Dixon L. E., Greenwood J. R., Bencivenga S., Zhang P., Cockram J., Mellers G., Ramm K., Cavanagh C., Swain S. M., Boden S. A. 2018. TEOSINTE BRANCHED1 regulates inflorescence architecture and development in bread wheat (Triticum aestivum). The Plant Cell, 30 (3): 563-581. https://doi.org/10.1105/tpc.17.00961

14. Dobin A., Davis C. A., Schlesinger F., Drenkow J., Zaleski C., Jha S., Batut P., Chaisson M., Gingeras T. R. 2013. STAR: ultrafast universal RNA-seq aligner. Bioinformatics, 29 (1): 15-21.

https://doi.org/10.1093/bioinformatics/bts635

15. Doebley J., Stec A., Hubbard L. 1997. The evolution of apical dominance in maize. Nature, 386: 485-488. https://doi.org/10.1038/386485a0

16. Ebel C., BenFeki A., Hanin M., Solano R., Chini A. 2018 Characterization of wheat (Triticum aestivum) TIFY family and role of Triticum durum TdTIFY11a in salt stress tolerance. PLoS ONE, 13 (7): e0200566. https://doi.org/10.1371/journal.pone.0200566

17. Feldman M., Levy A. A. 2012. Genome evolution due to allopolyploidization in wheat. Genetics, 192: 763-774. https://doi.org/10.1534/genetics.112.146316

18. Finlayson S. A. 2007. Arabidopsis Teosinte Branched1like1 regulates axillary bud outgrowth and is homologous to monocot Teosinte Branched1. Plant and Cell Physiology, 48 (5): 667-677. https://doi.org/10.1093/pcp/pcm044

19. Fowler D. B., Limin A. E. 1997. Breeding for winter hardiness in cereals. Acta Agronomica Hungarica, 45 (3): 301-309. 
20. Gemes K., Kim Y. J., Park K. Y., Moschou P. N., Andronis E., Valassaki C., Roussis A., Roubelakis-Angelakis K. A. 2016. An NADPH-Oxidase/Poly-amine Oxidase feedback loop controls oxidative burst under salinity. Plant Physiology, 172 (3): 1418-1431. https://doi.org/10.1104/pp.16.01118

21. Heitz T., Widemann E., Lugan R., Miesch L., Ullmann P., Désaubry L., Holder E., Grausem B., Kandel S., Miesch M., Werck-Reichhart D., Pinot F. 2012. Cytochromes P450 CYP94C1 and CYP94B3 catalyze two successive oxidation steps of plant hormone Jasmonoyl-isoleucine for catabolic turnover. The Journal of Biological Chemistry, 287 (9): 6296-6306. https://doi.org/10.1074/jbc.M111.316364

22. Hong G., Zhang W., Li H., Shen X., Guo Z. 2013. Separate enrichment analysis of pathways for up- and downregulated genes. Journal of the Royal Society Interface, 11 (92): 20130950. https://doi.org/10.1098/rsif.2013.0950

23. Hubbard L., McSteen P., Doebley J., Hake S. 2002. Expression patterns and mutant phenotype of teosinte branched1 correlate with growth suppression in maize and teosinte. Genetics, 162 (4): 1927-1935.

24. IWGSC. 2018. International Wheat Genome Sequencing Consortium. Appels R. et al. Shifting the limits in wheat research and breeding using a fully annotated reference genome. Science, 361 (6403): 661. https://doi.org/10.1126/science.aar7191

25. Koyama T., Furutani M., Tasaka M., Ohme-Takagi M. 2007. TCP transcription factors control the morphology of shoot lateral organs via negative regulation of the expression of boundary-specific genes in Arabidopsis. The Plant Cell, 19 (2): 473-484. https://doi.org/10.1105/tpc.106.044792

26. Laudencia-Chingcuanco D., Fowler D. B. 2012. Genotypedependent burst of transposable element expression in crowns of hexaploid wheat (Triticum aestivum L.) during cold acclimation. Comparative and Functional Genomics, 2012: 232530. https://doi.org/10.1155/2012/232530

27. Laudencia-Chingcuanco D., Ganeshan S., You F., Fowler B. Chibbar R. 2011. Genome-wide gene expression analysis supports a developmental model of low temperature tolerance gene regulation in wheat (Triticum aestivum L.). BMC Genomics, 12 (1): 299. https://doi.org/10.1186/1471-2164-12-299

28. Leonardos E. D., Savitch L. V., Huner N. P., Oquist G., Grodzinski B. 2003. Daily photosynthetic and C-export patterns in winter wheat leaves during cold stress and acclimation. Physiologia Plantarum, 117 (4): 521-531. https://doi.org/10.1034/j.1399-3054.2003.00057.x

29. Li Q., Byrns B., Badawi M. A., Diallo B., Danyluk J. 2018. Transcriptomic insights into phenological development and cold tolerance of wheat grown in the field. Plant Physiology, 176: 2376-2394. https://doi.org/10.1104/pp.17.01311
30. Love M. I., Huber W., Anders S. 2014. Moderated estimation of fold change and dispersion for RNA-seq data with DESeq2. Genome Biology, 15: 550. https://doi.org/10.1186/s13059-014-0550-8

31. Martin W., Herrmann R. G. 1998. Gene transfer from organelles to the nucleus: how much, what happens, and why? Plant Physiology, 118: 9-17. https://doi.org/10.1104/pp.118.1.9

32. Medeiros D. B., Fernie A. R., Araújo W. L. 2018. Discriminating the function(s) of guard cell ALMT channels. Trends in Plant Science, 23: 649-651. https://doi.org/10.1016/j.tplants.2018.06.006

33. Nakano T., Suzuki K., Fujimura T., Shinshi H. 2006. Genome-wide analysis of the ERF gene family in Arabidopsis and rice. Plant Physiology, 140: 411-432. https://doi.org/10.1104/pp.105.073783

34. Padmanaban S., Chanroj S., Kwak J. M., Li X., Ward J. M., Sze H. 2007. Participation of endomembrane cation/H+ exchanger AtCHX20 in osmoregulation of guard cells. Plant Physiology, 144 (1): 82-93. https://doi.org/10.1104/pp.106.092155

35. Park S., Lee C., Doherty C. J., Gilmour S. J., Kim Y., Thomashow M. F. 2015. Regulation of the Arabidopsis CBF regulon by a complex low-temperature regulatory network. The Plant Journal, 82: 193-207. https://doi.org/10.1111/tpj.12796

36. Pont C., Leroy T., Seidel M., Tondelli A., Duchemin W., Armisen D., Goué N. 2019. Tracing the ancestry of modern bread wheats. Nature Genetics, 51: 905-911. https://doi.org/10.1038/s41588-019-0393-z

37. Ruzgas V., Koppel R. 2017. The new winter wheat cultivars 'Kena DS', 'Gaja DS', 'Sedula DS' and 'Herkus DS' for increased yield stability. Zemdirbyste-Agriculture, 104 (4): 291-298. https://doi.org/10.13080/z-a.2017.104.037

38. Tondelli A., Francia E., Barabaschi D., Pasquariello M., Pecchioni N. 2011. Inside the CBF locus in Poaceae. Plant Science, 180 (1): 39-45. https://doi.org/10.1016/j.plantsci.2010.08.012

39. Zadoks J. C., Chang T. T, Konzak C. F. 1974. A decimal code for the growth stages of cereals. Weed Research, 14 (6): 415-421. https://doi.org/10.1111/j.1365-3180.1974.tb01084.x

40. Zhu A., Ibrahim J. G., Love M. I. 2019. Heavy-tailed prior distributions for sequence count data: removing the noise and preserving large differences. Bioinformatics, 35 (12): 2084-2092. https://doi.org/10.1093/bioinformatics/bty895

ISSN 1392-3196 / e-ISSN 2335-8947

Zemdirbyste-Agriculture, vol. 107, No. 4 (2020), p. 329-336

DOI 10.13080/z-a.2020.107.042

\title{
Trumpalaikis žemos temperatūros poveikis žieminių kviečių transkriptomui
}

\author{
A. Aleliūnas, K. Jaškūnè, G. Statkevičiūtė, G. Vaitkevičiūtė, G. Brazauskas, R. Armonienè
}

Lietuvos agrarinių ir miškų mokslų centro Žemdirbystès institutas

\begin{abstract}
Santrauka
Žema temperatūra sukelia genų raiškos pokyčius augaluose ir yra svarbiausias abiotinis veiksnys, lemiantis vidutiniu platumu klimato augalų užsigrūdinimą ir žiemkentiškumą. Tyrimo tikslas - įvertinti trumpalaikio žemos temperatūros poveikio metu indukuotus žieminio kviečio (Triticum aestivum L.) transkriptomo pokyčius taikant RNR sekoskaitos metodą. Tyrimo metu buvo aptikti reikšmingi branduolio transkriptomo pakitimai, tačiau organelių transkriptomo pokyčiai nebuvo ryškūs. Iš viso nustatyti 15042 branduolio genai su iš esmès pakitusia raiška dèl trumpalaikio poveikio žema temperatūra. Iš šio skaičiaus 2466 genų ekspresija buvo stipriai $(\log 2 \mathrm{FC}>2$ arba $\log 2 \mathrm{FC}<-2)$ paveikta. Vertinant atskiras chromosomų grupes, dèl poveikio šalčiu daugiausia genu buvo indukuota iš 5 ir 2 homeologiniu chromosomu grupiu. Iš visu tirtu labiausiai padidejusia raiška pasižymėjo genai CBFIIId-12.1, WRKY transcription factor 55-like ir genų grupė, siejama su fitohormono jazmonato signaliniu keliu.
\end{abstract}

Reikšminiai žodžiai: diferenciškai ekspresuojami genai, jazmonatai, RNR sekoskaita, šalčio sukeltas stresas, transkripcijos veiksniai. 